\title{
Development of Eia Guidelines of Significant Factors For Diamer Basha Dam Gilgit Baltistan
}

\author{
Wajahat Alia, Iqtidar Hussain ${ }^{b}$, Haroon Rashida, Abdul Nasira \\ a Department of Structures \& Environmental Engineering, University of Agriculture, Faisalabad \\ b Department of Environmental Sciences, Karakoram International University, Gilgit - Baltistan \\ *Corresponding Author Email: wajahatbagoro@gmail.com
}

\section{DOI: 10.2478/pjg-2020-0006}

\begin{abstract}
:
Energy crises is the one of the major problem that was faced by Pakistan in order to overcome on that crises Pakistan need to be developed and improvement in energy sector, Throughout in the country the demand of water and power increasing day by day therefore hydropower project are the need of the hour in Pakistan. Before initiation of any project EIA play important role in evaluating the nature of the project on different factors. Government of Pakistan planned one of the mega hydropower project diamer basha dam was planned in Gilgit Baltistan. It was intended to conduct the research work on describing significant factors so as to evaluate the influence of the project on them and develop guidelines for environmental assessment for these factors. To find out these significant factors the methodology was adapted to conducting field investigation. Besides to assess the relevant impact questionnaires were developed. Finally, in order to reduce the negative impact of the project on the predefine factor mitigation measure was suggested. It is anticipated that this study work support in developing structure work to be executed as mitigation measures and boost the advantages of the project.
\end{abstract}

Keywords: hydropower development, EIA, Basha dam, guidelines, mitigation measures

\subsection{Introduction:}

For each proposed project, environmental impact assessment (EIA) is a tool for decision making, used to recognize and estimate the likely environmental impacts of a proposed project [1]. EIA established in the United States, where it was primary presented by the National Environmental Policy Act (NEPA) of 1969, was executed in the European Union (EU) through Directive 85/337/EC, as modified in 1997 and 2003 and that was applied in the world more than one hundred countries today. In the presentation of an EIS to public and other stake holder, EIA is involved, it consists of different stages, e.g. screening and scoping [1]. EIA has three has three fundamental purposes first one is as "an aid to decision-making, second one is an aid to the formulation of the development actions, and third and last one is as an instrument for sustainable development". While the most two widely recognized purpose is as, the purpose of maintainable development subsequent from an ecologically sensitive project is of paramount importance [2]. Although principal aim of EIA is considered as sustainability [2,3]. EIA is viewed as less successful in achieving sustainability goals but it has led to enhanced environmental friendly decision [4]. Abundant study has been completed on the hypothetical prospects for EIA to accomplish sustainability, but there is slight experimental study on whether EIA realizes this goal in rehearsal $[5,6]$. One latent cause for the restriction of EIA in realizing the purpose of sustainability is the reality that there is no "exclusive" description of the idea of sustainable progress: "There is not any strong covenant as to what maintainable development is" [7]. Though, it is generally approved that it is twisted on the three supports of ecological, community and financial sustainability, i.e. the so-called "triple bottom line" method [8]. One of the utmost quoted descriptions of this perception is that of the Brundtland report which shows that a progress is sustainable if it encounters the requirements of the current group lacking negotiating the capability of upcoming generations to encounter their individual requirements [9]. Therefore, sustainability goals to realize both intragenerational and intergenerational equality [10]. Frequently, the word sustainability is allocated into "durable" and "feeble" sustainability, grounded on the "capital stock theory" of usual, anthropological and artificial capital [11]. The Federal Republic of Germany is a federal state with a three-tiered structure of government: The Coalition (national level), the Länder (federal states, provinces or regional level), and metropolises (local authorities or community level). Germany is a advanced societal market budget with a durable industrial foundation and individual of Europe's more thickly settled countries; however, it is also a state with an wide-ranging environmental regulation scheme [12]. The participation of an "environmental" or "green" party in the government has directed to a move in commercial conduct to more environmental approachable decisions (e.g. the withdrawing of all nuclear-powered stations in the subsequent era) [13]. The defense of the anthropoid and usual environment and the advancement of sustainable progress are between the utmost significant party-political responsibilities in Germany [13]. EIA was applied as an environmental administration device in edict to sponsor the environmental fortification based on the values of protection and sustainability [14]. Though present EIA rehearsal is created on approximately fifteen years of skill, and the overall usefulness of the German EIA structure is appreciated as respectable within the European Union, there has not been any study on the consequences in the framework of sustainability until now. In result, the degree to which EIA in fact attains and encourages maintainable progress in Germany is unknown. The main objective of this research work is to define the specific factors and environmental parameters along with the development of environmental impact assessment guidelines in order to study predefined factors and development of frame work for mitigation measures

\subsection{Material and Methods}

\subsection{Description of the region}

The Diamer Basha dam is situated at the downstream of Chilas closely around $40 \mathrm{~km}$ left from Chilas; it is in Gilgit- Baltistan which is head quarter of district Diamer, Area. Having coordinates $35032^{\prime} 30^{\prime \prime} \mathrm{N}$ and $730 \mathrm{~d} 36^{\prime} 25^{\prime \prime} \mathrm{E}$. This venture has been equipped by WAPDA and, the cost of building dam is almost 14 billion dollar 


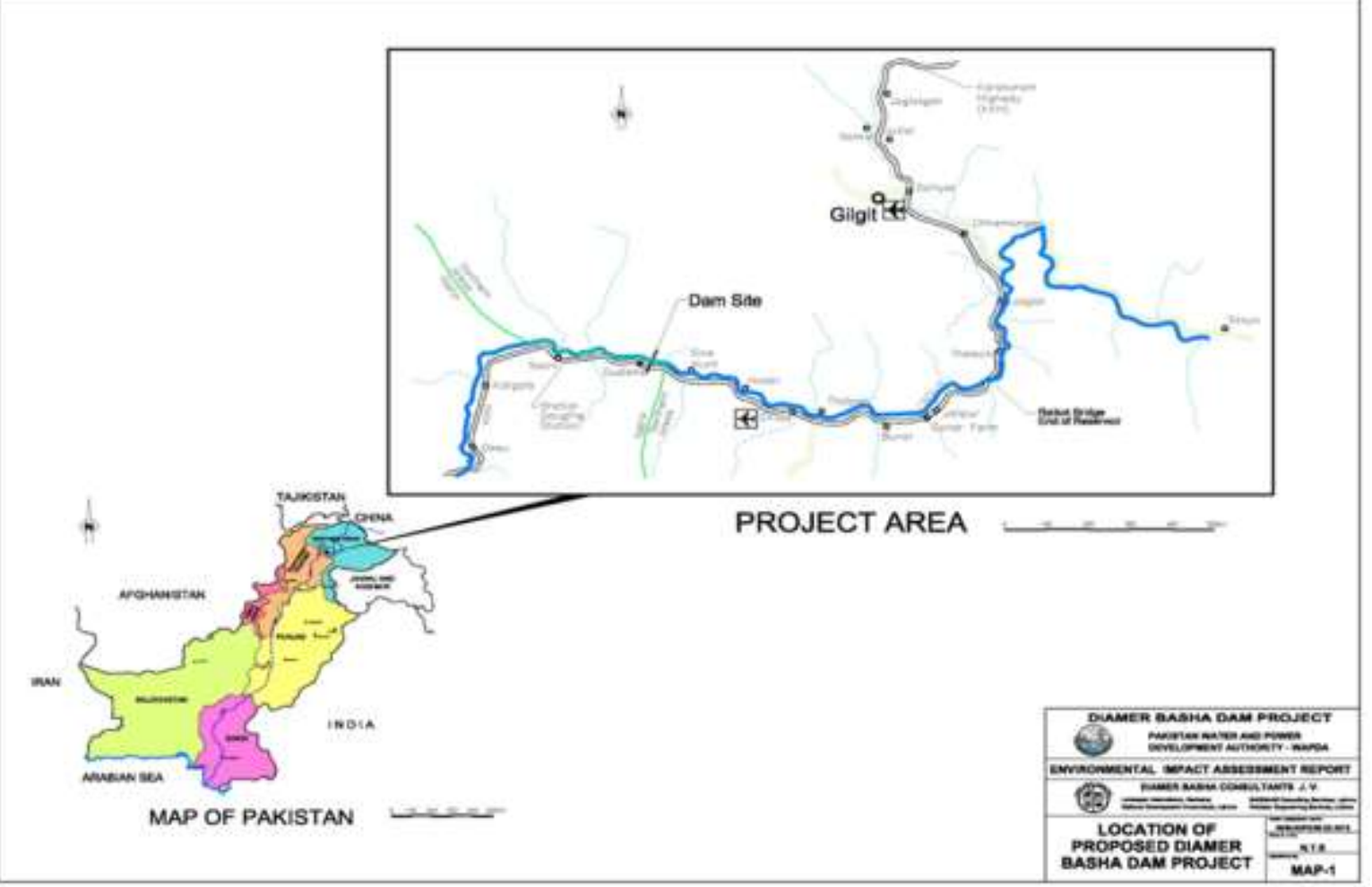

Figure 1: Location of Proposed Diamer Basha Dam Project

The dam will be slightly curved gravity structure of roller compacted concrete (RCC) with a crest level of 1,170 meters above sea level (masl) and crest length of over $1,000 \mathrm{~m}$. The maximum height will be $272 \mathrm{~m}$ above the firm rock foundation. Full reservoir level (FRL) will be 1,160 masl with minimum operating level (MOL) of 1,060 masl having a live storage capacity of 7.9 BCM. Figure 2.1 describes the site location of the dam.

\subsection{Research Design}

\subsubsection{Sampling}

It was a quantifiable study in environment. Specimen is a small demonstration of universe 'because of lack of time, charge and physical restriction it is additional inexpensive to study rather than the entire universe. The residents of sample for the study was 70 respondents of venture area and its nearby i.e. basha diamer dam project Gilgit but it was divided into two part, first one was for experts and second sample for community. Specimen were in proper form so the results were made on the basis of those 70 samples, out of which 30 for community were the local people (i.e. inhabitants, sellers, rickshaw drivers) and remaining 40 were the experts (i.e. engineer, site engineer, environmentalist)

\subsubsection{Research Strategy}

Questionnaire was a mail source of data collection in this research work and it's key purpose was to apply the information and facts to confirm or reject the research assumptions. In the survey most of the queries were open ended, as the important thing was to gain opinions, views also ideas of supporters and to obtain the findings of specific groups which were observed and could not be quantified on site. Thus, questionnaire was a through person to person argument on diverse levels. Other significant tip was the reliability of the research.

\subsubsection{Target stakeholders}

The objective partners who were the beneficiaries of the questionnaire were essentially the general population straightforwardly and by implication engaged with the dam venture advancement process and are influenced by the formative undertaking and its natural results, are arranged it into two gatherings, to be specific

- Community of dam site

- Experts of Gilgit Baltistan in the related department of dam

\subsection{Methodology}

\subsubsection{Baseline Survey of dam site}

The primary step to begin the study on Diamer Basha dam Gilgit was followed by base line study. The place where research was to be carried out, was thoroughly investigated for its demarcation, area or size, landscape closeness, sound level, traffic load etc. to come up with a precise environmental record. Base line study directed was chiefly in light of the data of nearby and specialized familiarity with the local together with financial issues. Both subjective and quantitative information was accumulated at dam site. Pattern information was normally. found in papers, in maps and databases, anyway sometimes supplementary field perceptions a perspective of kept networks were necessary.

\subsubsection{Site Identification and Selection}

The recognition of possible locations for any new development has to be assumed with the view of developing standards which differentiate the different setting restraints: substantial, security, environmental, community, economic, dogmatic and technological. The most significant aim of the Site assort should be: (Environmental impact Assessment for Waste Treatment and Disposal Facilities.

\subsubsection{Development of EIA Guides Lines}

A preliminary visit to the proposed landfill site was conducted in March 2018. Primary data collection was subsequently undertaken during March-May 2018. This included the collection of socio-economic survey, screening, impact identification and prediction, impact evaluation and mitigation measures. socio-economic baseline information through a standardized survey consist of questionnaire (Performa) focusing on household composition, general health status, livelihood strategies, and employment, the availability of utilities, and most importantly land acquisition and resettlement issues. A sample survey conducted diamer district of Gilgit Baltistan. 
Primary and secondary information was gathered through field observations, environmental observing in the apprehended, related departments and printed materials to establish summary for physical, biological and socio-economic situations of planned dam site

\subsubsection{Physical environment}

Information was composed on the current physical environment specific to as connected to geology, geography, topsoil, water quality, hydrology soil pattern, climate, land use, geomorphology

\subsubsection{Socio economic environment}

\subsubsection{Settlements}

Project impacted area extends over about $102 \mathrm{~km}$ of Indus River reach (reservoir stretch of $94 \mathrm{~km}$ ) upstream of the dam site almost entirely lying within Diamer District of N(GB)A with its headquarter at Chilas in the middle. Furthermore, the only areas suitable for housing and cultivation are along the Indus River itself and adjacent to many streams, local name "nullah" or "gah", at their outfalls. Water courses of these nullahs are often quite long and populated by many people, especially when they have sufficient water all over the year. Mostly the people in one valley belong to one ethnic group or tribe. That is why the population in each valley has a peculiar feeling of communal cohesion, and maintain intensive inter-village relationship. The valleys determine optimal interactions due to cultural, social and religious beliefs.

- Minar Significant manifestation is marriages between the families living within the valley.

Besides Chilas, some larger settlements such as Bunar Das and Gonar Farm have developed since completion of Karakorum Highway in 1977. Going upstream from the proposed dam site, the following sequence of 19 villages along Indus River can be found in the valleys (nullahs) on the left bank:

$>\quad$ Nullah: Lower Minar (1)

* Thor Nullah: Villages Sine Huch, Thor Das, Khotobat, Bazakal, and Muruski (5)

* Thurli Nullah: Villages Thurli Das and Chikka (2)

* Ghichi Nullah: Ghichi Village (1)

* Buto Nullah: Lower Chilas (1)

* Thak Nullah: Lower Thak (1)

* Gini Nullah: Lower Gini Village, local name 'Gini Hotel' (1)

* $\quad$ Bunar Nullah: Lower Bunar Das (1)

\subsubsection{Land Use}

\section{i. Cultivated Land}

The land use pattern is directly affected by the natural conditions, which are, in turn, dependent on the semi-arid to arid local climate and area relief. Cultivated land is only to be found in locations close to the perennial nullahs, where all settlements have been established.

There is almost no rain-fed agriculture. However, at some locations groundwater supplies along the wider alluvial fans of some nullahs are available. Due to running in deep gorge and high seasonal fluctuation, there can be no supply of irrigation water from the Indus River.

\section{ii. Rangeland}

Under the local climatic conditions, the prevalent vegetation in the area is a sparsely grassed steppe characterized by Artemisia plant associations. In general, all this land outside of the villages and palatines of the adjacent ranges called 'Dases' is used for grazing. Quality of this rangeland for livestock support is very poor. However, rangeland on moraines and terraces is more productive than that on rock outcrops covered only by thin alluvial deposits. Wet rangeland exists at very few places, where permanent and occasional ground or floodwater is available. These wet rangelands like at Thor Nullah, Buto Nullah, Thak Nullah, Khanbari Nullah, and Kiner Nullah, enable growth of high productive perennial grass.

\section{iii. Rocky and Sandy Areas}

There are many rock outcrops, cliffs, rockslides, and also sand banks and dunes, which do not have any vegetation cover. Very often, they are adjoining the rangeland areas.

\section{iv. Residential Land}

Land use, depicted in Map 3, illustrates the dispersed locations of residential area. The typical pattern in the project area is that residential land, except in upper Chilas Town, adjoins the cultivated land even in lower Chilas.

\section{v. Land for Business Facilities}

Business facilities are mostly located on the left bank of Indus River along Karakorum Highway covering small plots. To this land use category belong: builtup land with shops including wooden cabins; hotels; workshops; petrol / fuel filling stations; timber storage places; saw mills; and a few open landscapes

\subsubsection{Land Ownership Status}

Due to the historical genesis of Pakistan the land ownership conditions in Northern (Gilgit-Baltistan) Areas are quite different as compared to settled areas. Since independence from British colonial rule in 1947, Pakistan has exercised sovereignty over N (GB) A. Although N (GB) A is not defined as Pakistani territory under the 1973 Constitution, it is being governed by the Federal Government since 1951 (In September 2009, the area was granted autonomous status by the Government of Pakistan and renamed 'Gilgit and Baltistan'). Thus, some tribal rules and former principalities have continued to be applied. Management and institutions of natural resources are governed by a combination of legal instruments including common law dating back to the colonia administration of India (Land Acquisition Act 1894 predominantly), and Pakistan federal and provincial statutes. Cultivated and residential land in the vicinity of settlements was initially given to the migrant population virtually as tenancy. Adoption of current 'Northern (Gilgit-Baltistan) Areas Nautor Rule'(1980) envisages that the occupant of land will be treated as its owner. All other land beyond the settlements, mostly barren in the form of 'Dases' will belong to the Northern (Gilgit-Baltistan) Areas Administration. As already mentioned this has been a cause of prolonged dispute between the tribes and NA (GB) in the courts. However, as mentioned earlier that the parties have now shown willingness for an out of court settlement.

As already mentioned, in the project area, land records are almost non-existent. Neither a landowner nor a tenant has any document, record or certificate about his property. No revenue map is available with the District Administration except lists (handwritten) of households occupying the land including its use for residential and agricultural purposes. The ownership on land, tenure-ship, possession of houses and other properties are confirmed by Jirga of the village in cases of dispute. To overcome this difficulty, a Cadastral Survey had to be conducted during 2007

\subsection{Survey Observations}

\subsection{Environmental issues}

There is absolutely environmental issues generated due to construction of dam from where $43.33 \%$ of the people highlighted the main environmental 
issue related to project are air pollution, solid waste pollution and traffic congestion, $20 \%$ of the people said that this project generated issues related to water ,solid waste and traffic congestion, $10 \%$ people said that project generates issues related to water air and solid waste and $26.66 \%$ of the people said that due this project issue generated are air, water and traffic congestion

\subsection{Mitigation Measures}

For the mitigation of traffic congestion its should be banned on the NCP vehicles in the project area, bund formation along the river side to save water from turbidity during working time and solid waste from working site should be dumped in the specific place

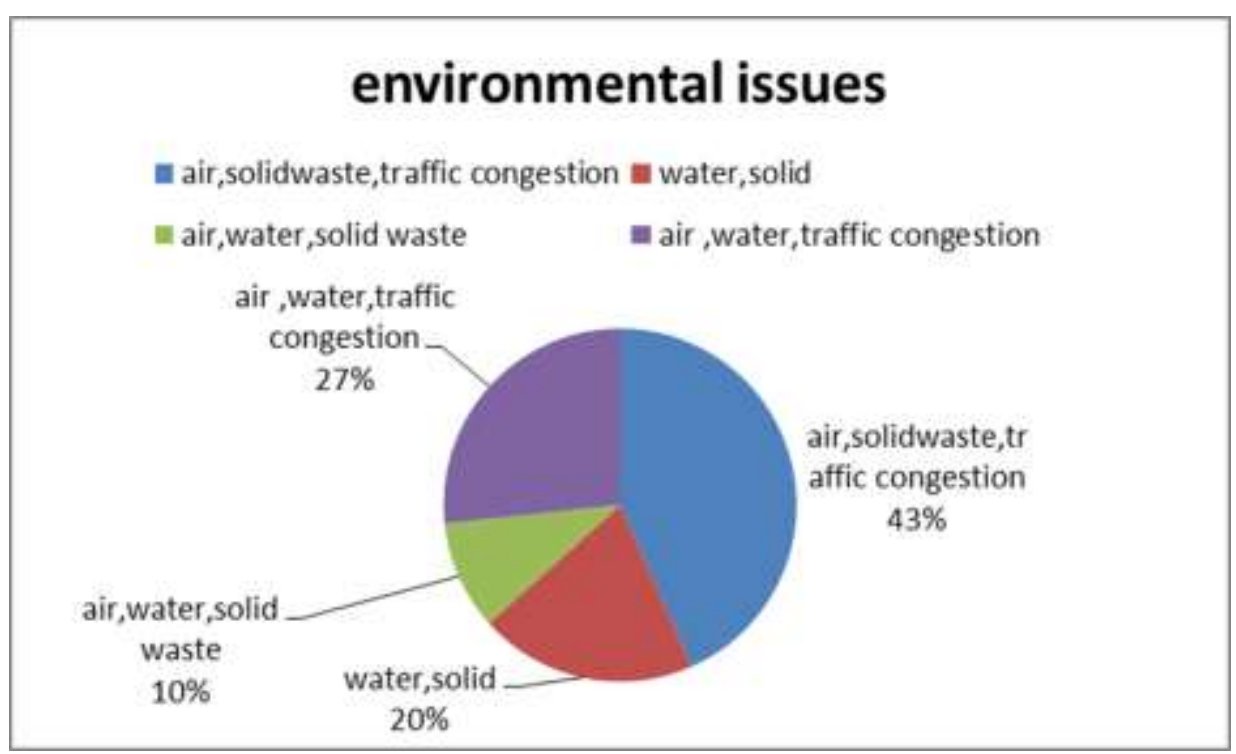

Figure 1: Environmental issues observation at site

\subsubsection{Area of farm land submerged by reservoir}

Figure 1 represents area that submerged in the reservoir of community most of the people have submerged their land greater than 20 kanal having percentage of $36.66 \%$ after that $30 \%$ of the people having submerged area is almost 5 kanal, and $7 \%$ of community said that we have submerged area of farmland is 10 kanal and $26.66 \%$ people said that we have no farm land submerge on the reservoir.

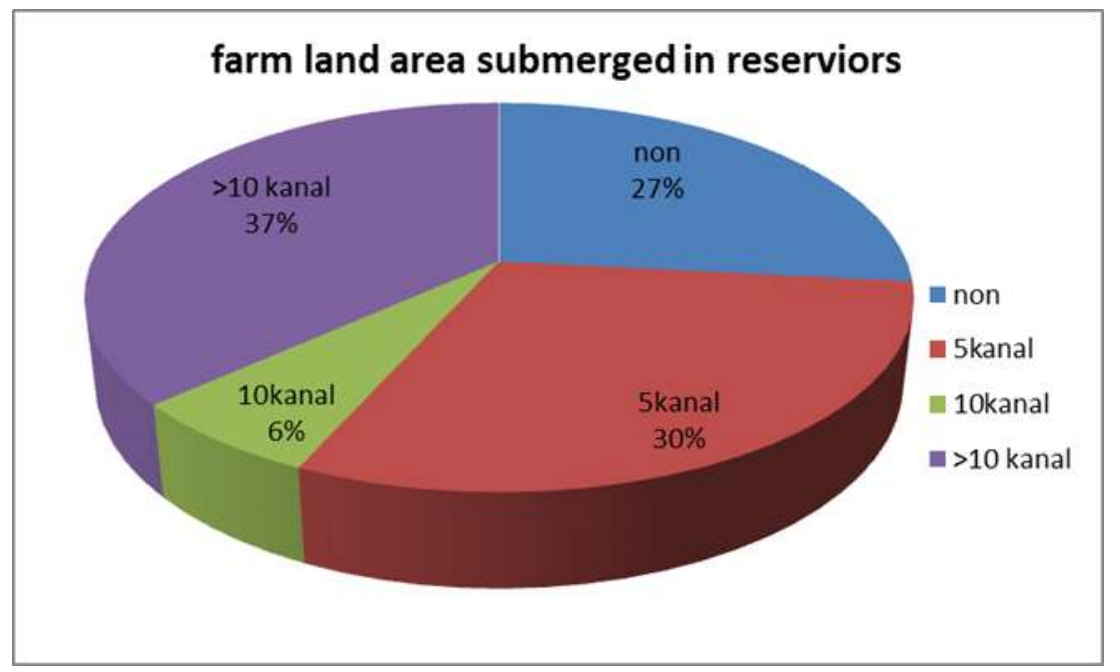

Figure 2: Farm Land Area submerged in reservoirs

\subsection{Recommended Mitigation measures}

$>$ Information and consultation with communities

$>$ Preparation / construction of bypassing routes for herds, if necessary, for transhumance

$>$ Consultations with shepherds about:

○ construction work schedule

- extent of rangeland occupation

- compensation for any damage of fodder resources

$>$ Compensation of business losses and offering of locations for replacement could be a further mitigation measure for the owner and workers of the timber storage.

$>$ After completion of the construction works, the land not needed for further use could be resituated to the villagers and owners

\subsection{Residential area submerged in the reservoirs}

Resident Area submerged in the reservoir are as $23 \%$ people have 1 kanal of resident area is submerged similarly $27 \%$ people have submerged area is 2 kanal and $10 \%$ people have less than three kanal rest of $40 \%$ had not submerged their residential area which shown in Figure 3. 


\section{Resident area submerged by the reservoir}

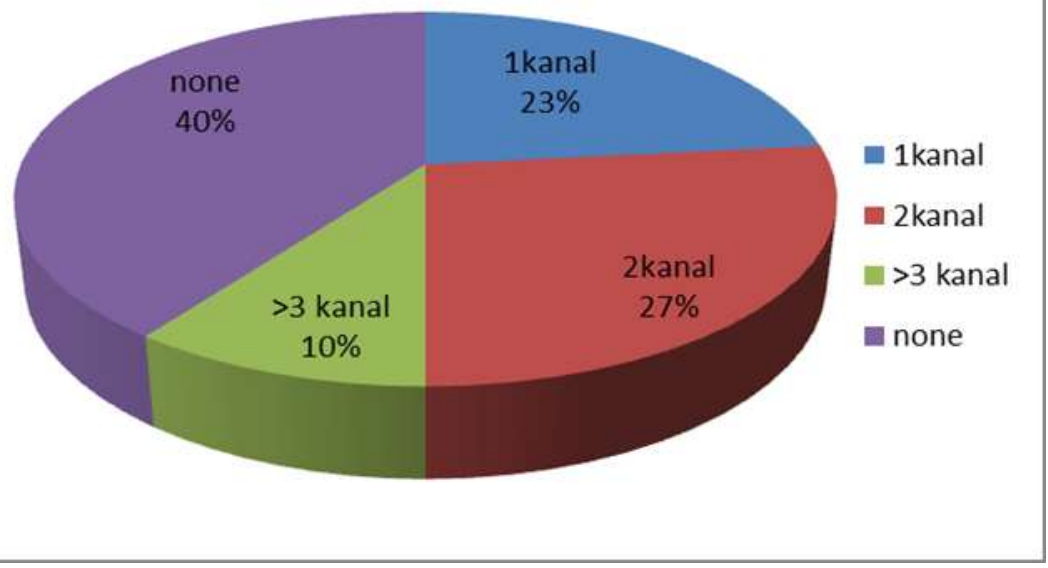

Figure 3: Resident area submerged by the reservoir

\subsection{Recommended Mitigation measures}

There is no possibility for mitigation measures on site However, the entire livelihood of affected population including settlements, houses and population will have to be restored. These measures form the part of companion document of 'Resettlement Plan'.

\subsubsection{Area of shop effect in dam}

Area of shop affected in the project area where $13 \%, 7 \%, 7 \%$ and $73 \%$ people had been asked that their affect area was $>3 \mathrm{kanal}, 2 \mathrm{kanal}, 1 \mathrm{kanal}$ zero kanal respectively as shown in Figure 4.

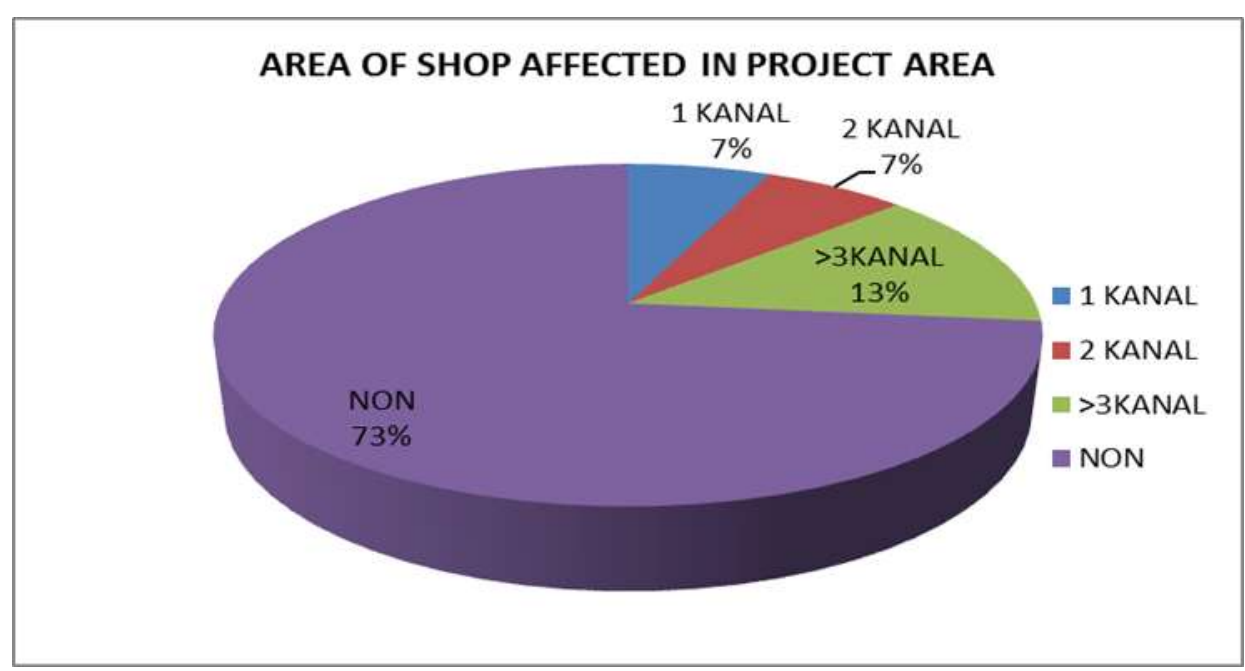

Figure 4: Area of Shop affected in Project area

\subsection{Recommended Mitigation measures}

For the mitigation of area of submerged shop it should be provide proper compensation and royalty of that shop that are under submerged in the project area.

\subsubsection{Trees effect in the dam site}

Trees affected in the project area where $23 \%, 3 \%, 3 \%, 34 \%$ and $37 \%$ people would be the affect area was $>3 \mathrm{kanal}, 2 \mathrm{kanal}, 1 \mathrm{kanal}, 0 \mathrm{kanal}$ respectively which are shown in Figure 5. 


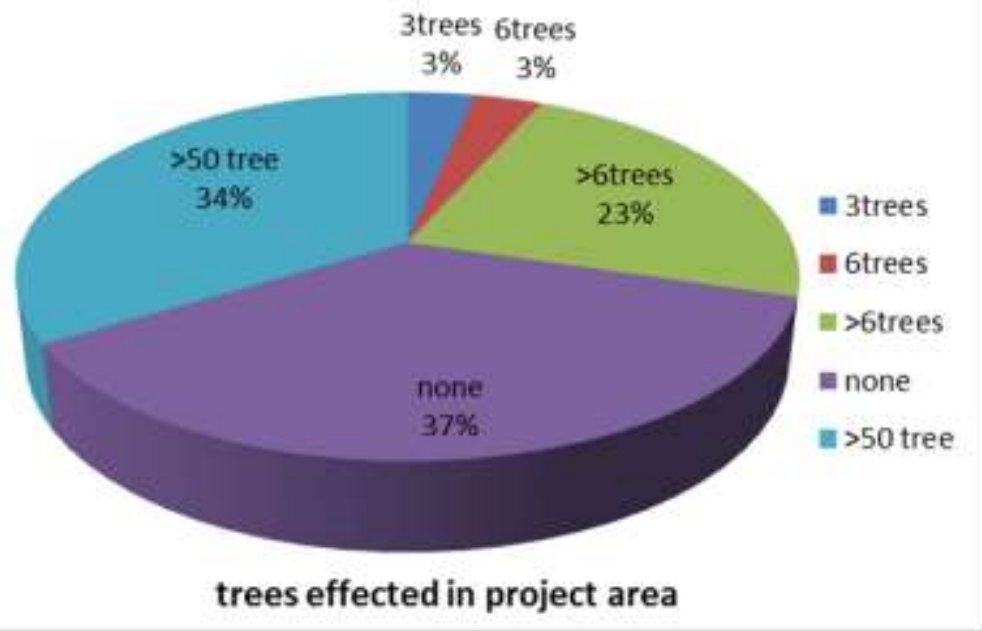

Figure 5: Trees affected in Dam Site.

\subsection{Recommended Mitigation Measures}

Based upon this inventory, appropriate mitigation measures will have to be devised, implemented and monitored. The significant loss of 525,775 trees in the reservoir area could be mitigated through: -

$>$ Full compensation for the lost trees including free salvage of wood

$>$ Removal of some adult trees to the new locations, if possible

$>$ Re-planting of trees in new locations (Model Villages, new / relocated roads and the buffer zone between 1160 and 1170 masl)

Removal of adult trees is being followed in some large international projects. Under this approach, the people are offered transportation to the new resettlement locations. This measure can also create favourable conditions for construction of new houses in the Model Villages. However, this approach for this particular case may fail due to the size of trees and transportation difficulty.

3.6.1. Is there any archeological and culture site or building in the project site?

$70 \%$ people think that there are archeological and culture site or building in the project site of dam but $30 \%$ people would have response that there is no archeological and culture site in the project area which show in a chart given in Figure 6.

\section{is there any archeological ,cultural site or building the the project area?}

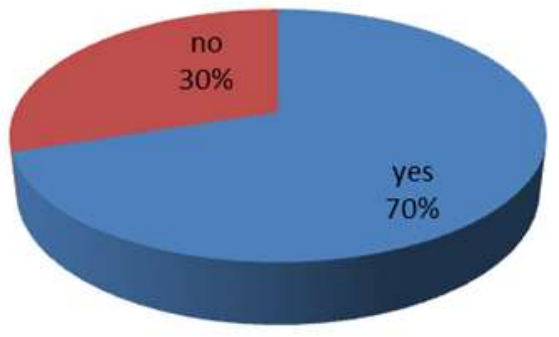

Figure 6: Archeological, cultural sites at project area

\subsection{Recommended Mitigation Measures}

This will include the following mitigation measures required either to avoid or reduce negative impacts:

$>$ Review / refinement of the available detailed inventory of the rock carvings in the project area

$>$ Prior supplemental field investigations at various construction sites for identification of additional objects in close cooperation with Dept. of Archaeology and Museums of Pakistan

$>$ Confirmation of the list of identified 'Most Important Rock Carvings'

$>$ Determining feasibility of relocation among the 'Most Important Rock Carvings'

$>$ Documentation of the remaining 'Most Important Rock Carvings' through 3-D Scanning and Replication

$>$ Construction of Rock Carvings Exhibition Centre in Chilas to display the salvaged rock carvings Out of 31423 carvings on 5202 rocks, about 109 would be replicated including a few relocated, if possible. As mentioned above, this is proposed to be accomplished through a 'Cultural Heritage Management Plan'. 
employment in area, $7 \%$ people asked that the area become commercial due to project, $40 \%$ people expressed that due to project there is increment of labor in project area but 13\% people said that there is no creation of employment in area due to this project as shown in Figure 7.

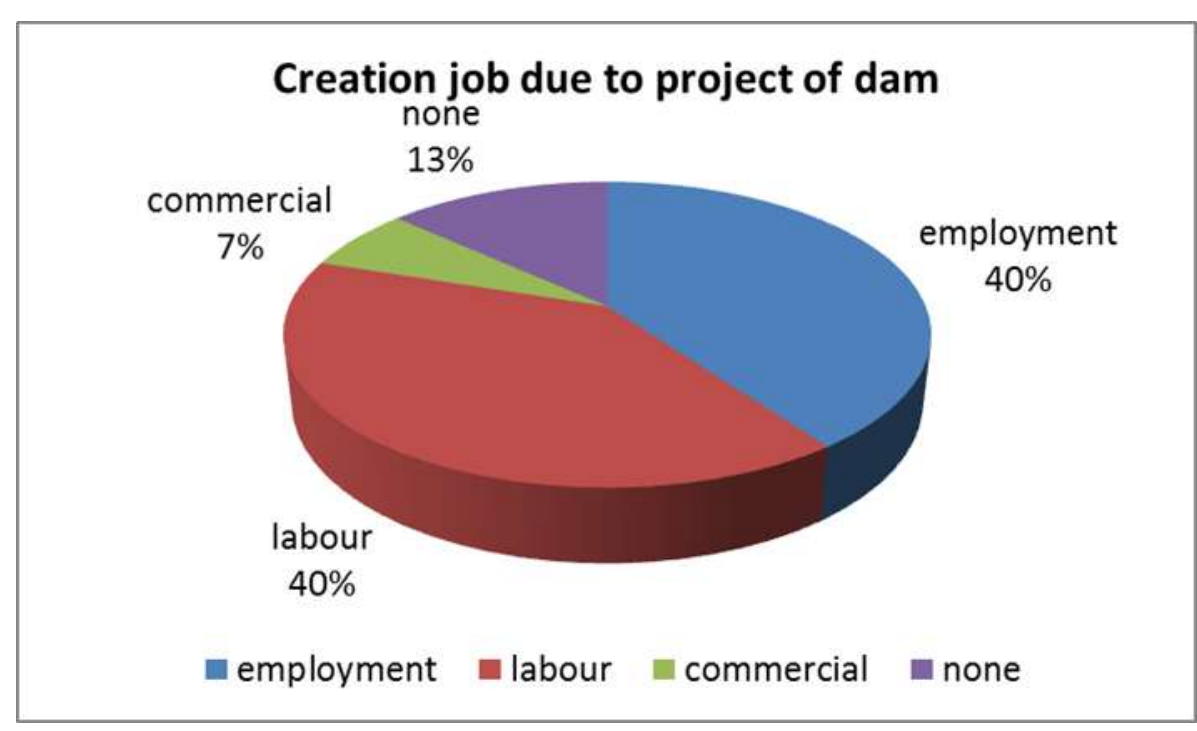

Figure 7: Job opportunities due to project development

3.8. Recommended Mitigation Measures

Supporting measures to overcome the above described unfavorable conditions are as follows:

$>$ Strengthening of existing vocational training facilities in Chilas with WAPDA and other concerned national / regional agencies to improve employment prospects of locals

$>$ Development of basic education and vocational training facilities, particularly in the Model Villages to resettle PAPs

$>$ Specialization to impart computer skills to the locals through introduction of preparatory measures in the basic education and vocational training as well

$>$ Preferential employment of locals, particularly for non-skilled jobs through standing arrangements between WAPDA / contractors and Northern (Gilgit-Baltistan) Areas Administration

3.8.1. Is there a possibility that the project will damage the local historical culture and religious heritage?

The project would damage a lot of mosque and historical place but from the research $45 \%$ of the people said that there would be damage of cultural and religious heritage would be moderate, $35 \%$ of the people said that the damage of religious and cultural heritage would be high, $13 \%$ of the people said that it would be low and $7 \%$ of the people said that it would be no damage of the cultural and religious heritage which shown in Figure 8.

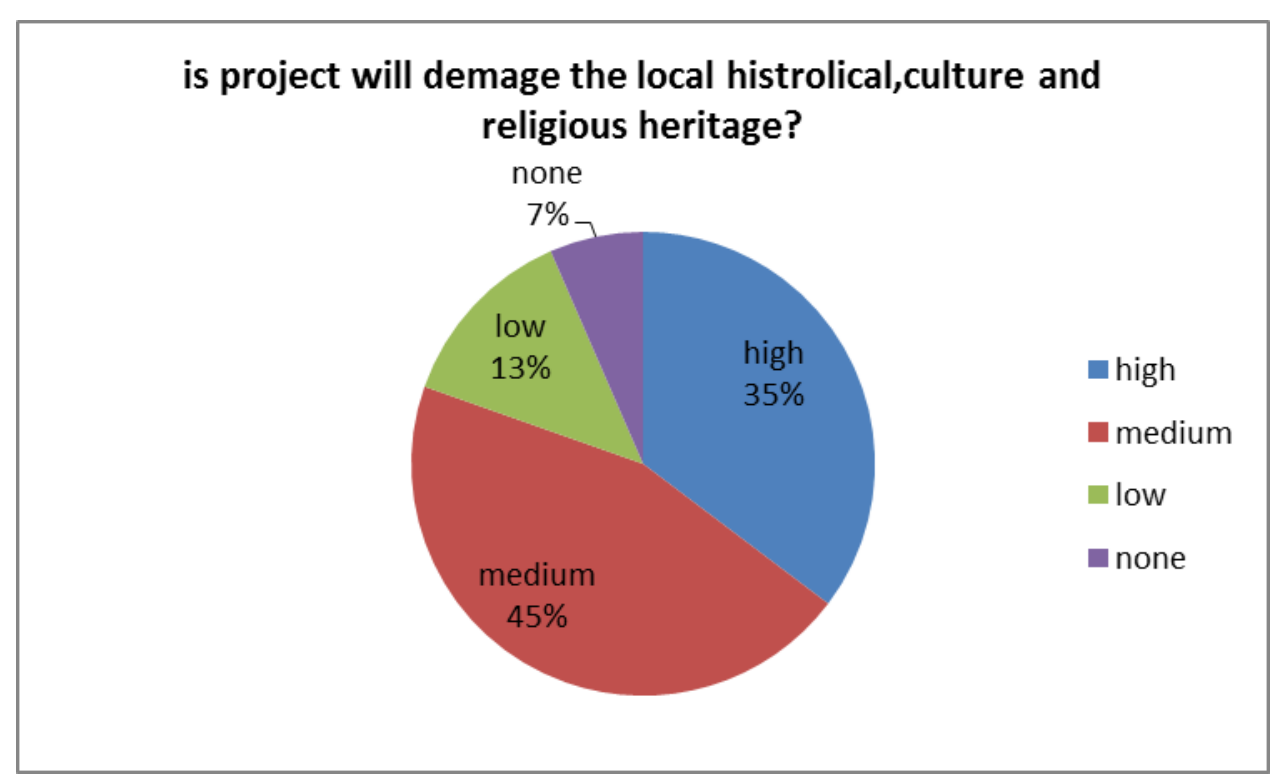

Figure 8: Local historical, cultural and religious heritage

\subsection{Recommended Mitigation Measures}

$>$ Provide alternate place for religious, cultural and local historical place for relocation

\subsubsection{Is there any resettlement of the land issues in the project area?}

Definitely the resettlement issues might be possible during the reservoir formation of dam there would be at least 31 village are submerged but the 80 local people of sthat said that there would be a resettlement land issue of the people of the area of project but $20 \%$ said that there would be no resettlement land issues which are shown in Figure 9. 


\section{is there any resttlement of land issues in project area?}

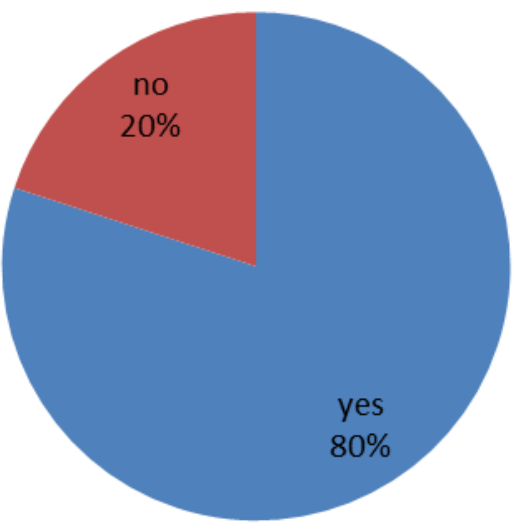

Figure 9: Resettlement of land issues

\subsection{Recommended Mitigation Measure}

$>$ It is not possible to resettle the migrants at their desired places however, the entire livelihood of affected population including settlements, houses and population will have to be restored.

\subsubsection{Do this project have badly impact the agriculture productivity and land?}

During the formation of reservoir of the dam there were 31 villages that are submerged in the reservoir its means that there would be badly impact on the agriculture productivity and land but the $67 \%$ of the respondent said that there would be badly effect on the agriculture productivity and $33.33 \%$ of the people said that there would be no effect on the agriculture productivity and land. The results are shown in Figure 10.

\section{do this project badly impact the agriculture productivity and land?}

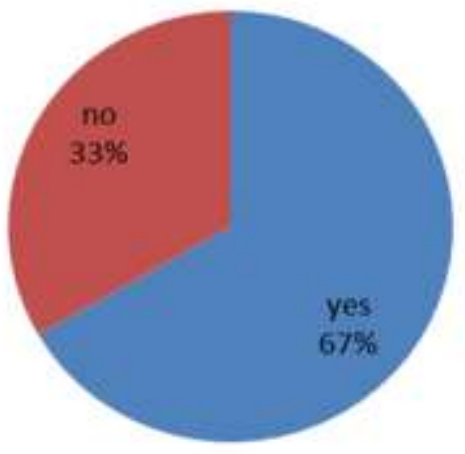

Figure 10: Impact on agricultural productivity and land

\subsection{Recommended Mitigation Measures}

No particular mitigation measures will be required but the activity might have to be properly managed. It can be seen that a sizeable chunk of land measuring 3690 ha (9114 acres) could be brought under recession agriculture through proper planning and implementation. Similar to experience at Tarbela reservoir, the farmers in this case will have the opportunity to cultivate the land vacated during the drawdown period of October to May. The land, containing reservoir moisture, could be beneficially used to grow medium- and short-term crops, particularly fodders. For optimum development of this significant potential, active association of the local Agriculture / Forest Departments will be necessary. However, the primary role will be played by the operating agency of WAPDA. It may involve formalization of arrangements to encourage recession agriculture through: -

$>$ Leasing

$>$ Advising the farmers, on season to season basis, about progressive anticipated availability of lands for cultivation.

$>$ Advance information for timely evacuation of land according to reservoir impounding schedule.

Regarding agronomic aspects, crop zoning and non-water inputs, the technical advice to farmers will be provided by the Agriculture Department through its Extension Service

\subsubsection{Do you think this project have created loss of geomorphological important structure?}

Geomorphology is the basically study of the physical feature of the surface of the earth and their relationship to geological structure of earth ,in this research $70 \%$ people said that there would change in physical feature due to dam and $30 \%$ people said that there would be no change in physical feature of project area. The results are shown in Figure 11. 


\section{is geomorphological losses due project?}

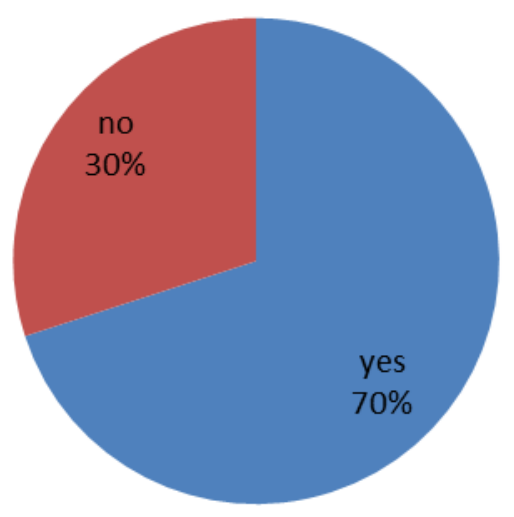

Figure 11: Geomorphological loss due to project

\subsection{Recommended Mitigation Measures}

Mitigation measures are not required as far as the geology is concerned. In the case of landscape beauty the loss of the typical high mountain valley seems to be balanced with the establishment of a beautifully high mountain "lake". The reservoir operating agency (WAPDA) will be well advised to support enhanced recreation and tourism in the region in cooperation with the concerned regional / national agencies

\subsubsection{Do this project enhance the social and economic uplift?}

Most of the people would express their view that due the project of dam the local people of that area would have strong their economy and also socially become too strong the comment of the people are shown in the chart given below.

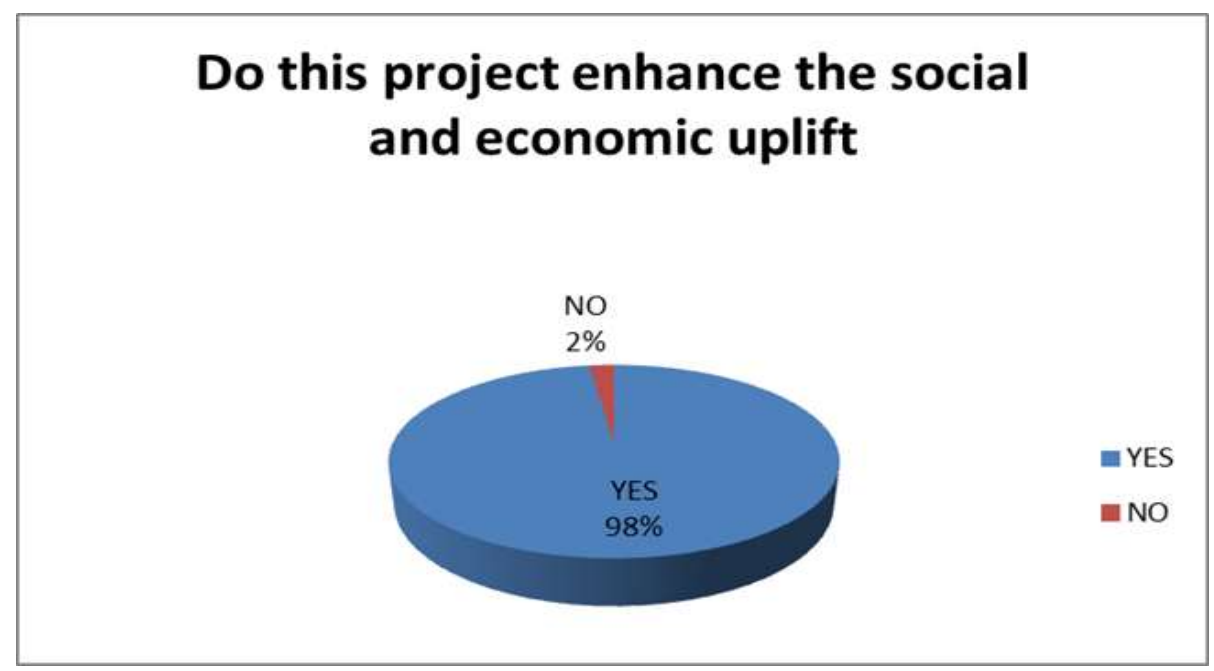

Figure 12: Do this project enhance the social and economic uplift?

\subsection{Recommended Mitigation Measures}

Figure 12 has shown that there has been no significant observation found regarding the research question being observed. In this regard it is not required to take any measures and there is no need to develop mitigation plan for this matter.

3.13.1. Social conflict and issues arise due project of dam

For the compensation of the project there would be enhancement in illegal grabbing of land, quarrelsome, deprivation would be found among community their relative percentage is shown in Figure 13. 


\section{social conflict and issues araise due project of dam}

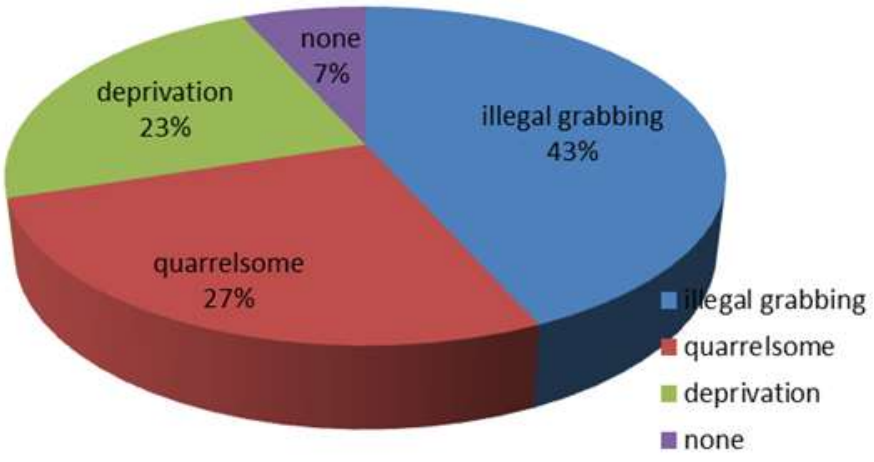

Figure 13: Social conflict and issues arise due project of dam

\subsection{Recommended Mitigation Measures}

It should be guided through the prescribed strict rules of conduct and behavior in the project area for the male workers. Contractor(s) security personnel including their public relation staff would be prepared for this aspect and to do everything possible to avoid any tensions. Most valuable and regular advice to expatriate construction workers will be to respect ethical values. Contractor(s), in cooperation with Diamer District Administration and WAPDA, will introduce regular monitoring processes to watch implementation of any appropriate mitigation measures for reducing the risk of deterioration of social life

\subsubsection{Air pollution due to project of dam}

Due to working of different machinery there is a lot of pollution in the site area of project due to which air would be polluted where $17 \%$ people said in site area of project there would be high air pollution and 30\% people point of view was that air pollution would be low at site ar ea of project and $53 \%$ people predicted air pollution would be medium and $0 \%$ said no air pollution in the site area.

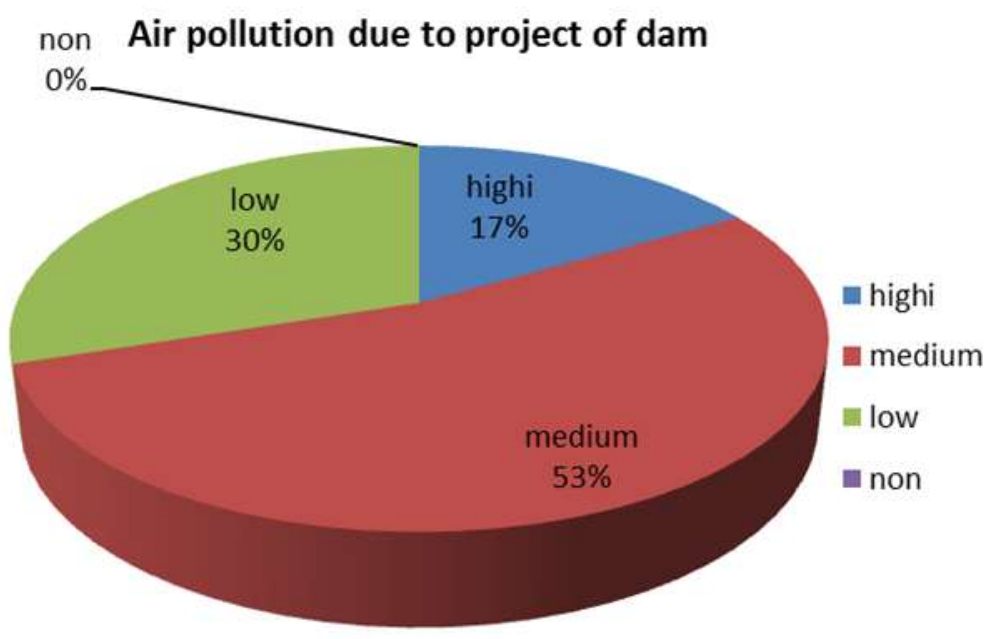

Figure 14: Air pollution effect due to project

\subsection{Recommended Mitigation Measures}

$>\quad$ Mitigation measures would be required as outlined below:-

$\circ \quad$ Use of modern vehicles with low emission standards

- Plying of heavy traffic during night time in order to minimize exposure of people against emissions

○ Reconstruction of KKH bypassing the settled areas.

Due to very distant location of various project construction sites, the threat of air pollution is negligible. However, the construction contractor(s) will be under obligation to minimize emissions and direct impact on receptors.

\subsubsection{Noise pollution due to project of dam}

There will be a lot of machinery which would be used in the project area for different working purpose during there working there would be a lot of noise created where from conducted survey $13 \%$ people said that there would be high noise created in the area and $57 \%$ people expressed that there would be medium noise created from project site and $27 \%$ people said that there would be low noise created in the vicinity and $3 \%$ said that there would have no noise in the vicinityodern machinery and vehicles with low emissions 


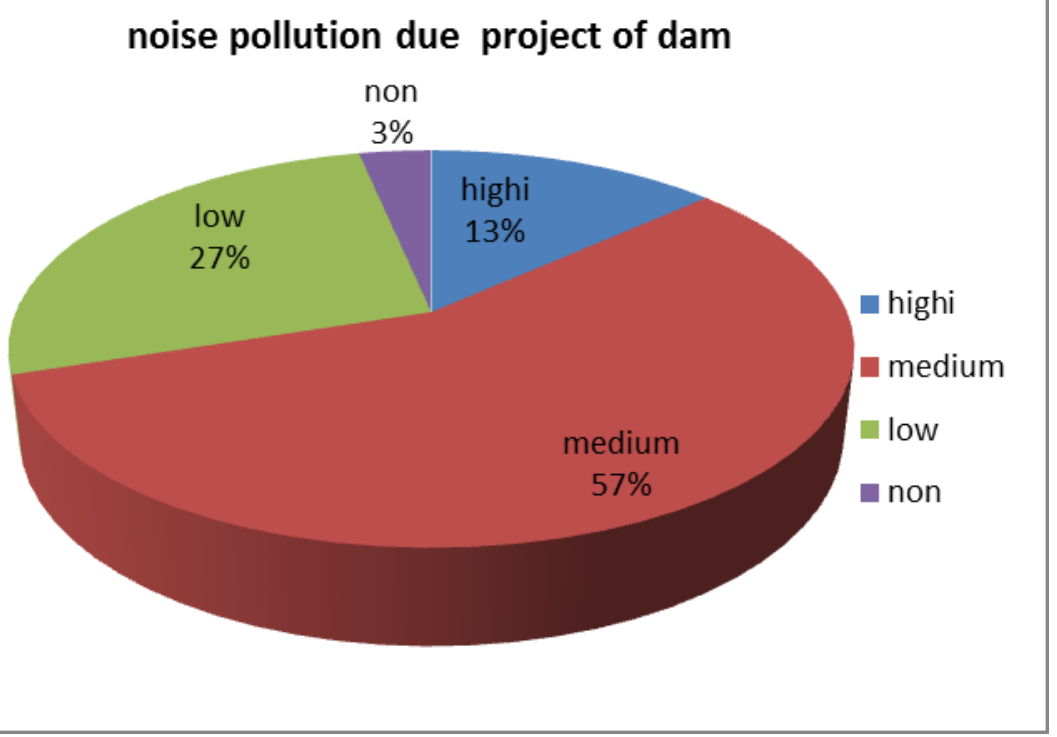

Figure 15: Noise Pollution due to project of Dam

3.16. Recommended Mitigation Measures

Contractor(s) would be obliged to reduce, as much as possible, the noise pollution. This will require measures such as:

Using modern equipment including heavy vehicles and trucks

$>$ Using appropriate protection devices for workers

$>$ Avoiding any drives into settled areas, especially at night

3.16.1. Construction of diamer basha dam and its effect on the climate and health of the region

According to $27.5 \%$ expert there would be high change in the climate and health of region due to construction of dam, 55.5\%of the experts said that there would be a moderate change in the climate and health of the region due to project $17.5 \%$ expert show their view that that there be low change in climate and health of the region and $2.5 \%$ expert said that there would be no change which shown in below the diagram.

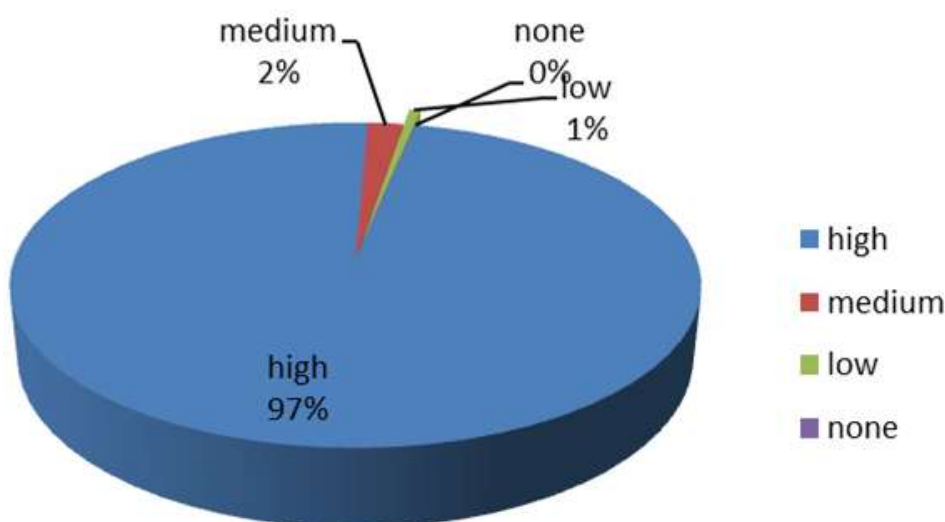

\section{do you think the construction of dam will affect the climate and weather of region}

Figure 16: Effect on climate change

\subsection{Recommended Mitigation Measure}

In order to cope with changing impact on climate and weather, the nature conditions must be restored, and the original scenario must be retained at the most. Following steps must be taken as mitigation.

$>$ To conserve nature, trees, plants, animals and other habitat as much as possible by developing controlled and monitored natural parks in the area.

$>$ To develop artificial forests in the study area and conduct plantation activity on regular basis. A target quantity of trees must be ensured on seasonal basis.

$>$ Natural lakes need to be constructed in the study area to cope with issues of water scarcity and to maintain the ecosystem balance in the environment.

\subsubsection{Seismic shaking, flooding or high-water condition}

$55 \%$ expert said that the project would produce situation of seismic shaking, flooding or high-water condition and $45 \%$ of the expert said that the project would not produce situation of seismic shaking, flooding or high water condition. Findings are shown in Figure 16. 


\section{do you think that this project produce seismic,shaking ,flooding or highi water condition?}

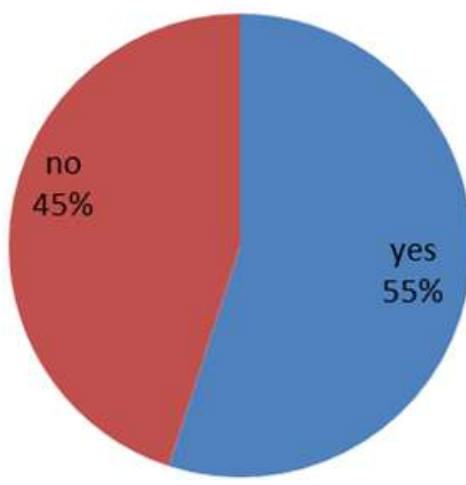

Figure 17: Seismic shaking, flooding or high-water condition

\subsection{Recommended Mitigation Measure}

In order to cope with significant probability regarding seismic, shaking, flooding or high-water conditions, the designing of the structure must be earthquake resilient, having capacity to bear unpredictable load and shaking. The structures should be lighter in weight to avoid any kind of unavoidable structure unbalance or failure.

\subsubsection{Increment impact on water quality resulting from the reservoirs}

$22.2 \%$ expert said that this project would high contribute to increment impact on water quality resulting from the reservoirs, $42.5 \%$ expert said that this project would medium contribute to increment impact on water quality resulting from the reservoirs, $22.5 \%$ expert said that this project would low contribute to increment impact on water quality resulting from reservoirs.12.5\% experts said that this project would low contribute to increment impact on water quality resulting from the reservoirs as shown Figure 18.

\section{do you think that the project will contribute to incremental impact on water quality resulting from reserviors?}

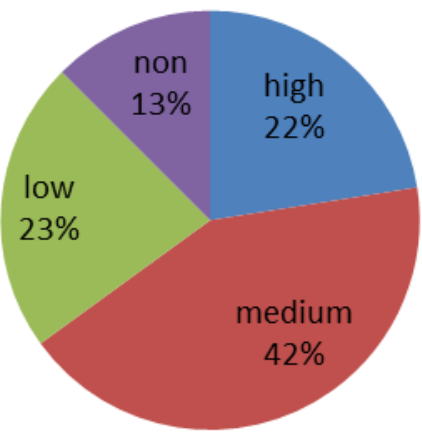

Figure 18: Increment impact on water quality resulting from the reservoirs

\subsection{Recommended Mitigation Measures}

In this case as significant is expected for water quality deterioration, wetland construction can one of most suitable options to improve the water quality for the flora and fauna. While for drinking purpose, proper drinking water treatment plant must be available for the community nearby.

\subsubsection{Effect on Land sliding}

$72.5 \%$ expert said that the project activities would enhance land sliding and $27.5 \%$ expert said that the project activities would not enhance land sliding which shows in Figure 19. 
do you think that the project activity will enhance land sliding?

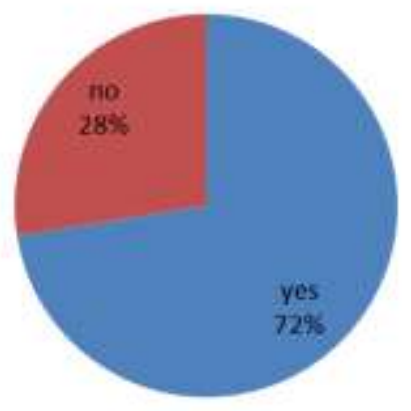

Figure 19: Effect on Land sliding due to Project

\subsection{Recommended Mitigation Measures}

In order to reduce the impact of land sliding on the study area, the most appropriate approach is to focus on constructing embankments as well as intense tree plantation on the slopes of mountains.

\subsection{Conclusion}

Construction of Diamer Basha Dam Project including its reservoir would significantly change the environment of the area through the following impacts:-

$>$ Relocating almost 30,000 peoples from their homes in 31 villages

$>$ Submerging cultivated and rangeland, thus denying the essential food, economic base, particularly of local farmers

$>$ Altering the natural river regime through establishing a reservoir with large seasonal fluctuations, river channel erosion and sedimentation

$>$ Adversely impacting cultural heritage through submergence of a large number of unique rock carvings

$>$ Submerging the habitats of amphibians, reptiles and birds

Under adverse impacts, the most severe would be relocating / resettling a large portion of local population. Submerging their homes, severing their socioeconomic activities of cultivation and animal husbandry and deteriorating the social structure of traditional villages and neighborhoods would have to be considered as the most serious implications.

During designing stage it has seriously considered the prevention / minimization of sever environmental changes through appropriate adjustments in the design.

On the other hand, there will be accrual of very large positive benefits to economy of the entire Pakistan through: enhanced irrigation supplies; 35 years prolonged useful life of Tarbela Dam; economic growth of millions of Pakistani peoples; contributing over $19000 \mathrm{GWh}$ of energy per annum to the national power grid; and avoidance of sizeable greenhouse gas emissions to retard the global warming. Notwithstanding this, the Government and WAPDA are endeavoring to contain / mitigate negative impacts of the project on the local environment

\section{References}

[1] J. Glasson, R., and Therivel, A., Chadwick, "Introduction to Environmental Impact Assessment”, Second Edition. UCL Press, London, 1999.

[2] B. Sadler, "Environmental assessment in a changing world: Evaluating practice to Improve performance", International Study of the effectiveness of environmental assessment, 1996.

[3] J. Petts, "Canadian Environmental Assessment Agency, Canberra, Australia”, Handbook of Environmental Impact Assessment. Volume 1. Environmental Impact assessment: Process, methods and potential. Blackwell Science, Oxford, 1999.

[4] L.K. Caldwell, "Achieving the NEPA Intent: New Directions in Politics, Science and Law. In: Hildebrand, S.G.; Cannon, J.B. (eds.). Environmental Analysis", The NEPA Experience. Lewis Publishers, London, 1993.

[5] D. Devuyst, T. van Wijngaard, and L. Hens, "Implementation of SEA in Flanders: Attitudes of Key Stakeholders and a User-friendly Methodology", Environmental Impact Assessment Review, vol. 20, no. 1, pp. 65-83, 2000.

[6] M. Cashmore, R. Gwilliam, R. Morgan, D. Cobb, and A. Bond, "The Interminable Issue Of Effectiveness: Substantive Purposes, Outcomes and Research Challenges in the Advancement of EIA Theory", Impact Assessment and Project Appraisal, in press, 2004.

[7] T. O’Riordan, “The Sustainability Debate. In: O’Riordan, T. (ed.). Environmental Science for Environmental Management”, Second Edition. Prentice Hall, London, pages 29-63, 2000.

[8] R. Goodland, and H. Daly, “Environmental Sustainability: Universal and Non-Negotiable”, Ecological Applications, vol. 6, no. 4, pp. 1002-1017, 1996.

[9] World Commission on Environment and Development (WCED). “Our common future”. Oxford University Press, Oxford, 1987.

[10] D. Pearce, A. Markandya, and E.B. Barbier, "Blueprint for a Green Economy”, Earthscan, London, 1992.

[11] R.K. Turner, D. Pearce, and I. Bateman, “Environmental Economics: An Elementary Introduction”, Prentice Hall, London, 1994.

[12] Umweltbundesamt (UBA), "A Guide to Environmental Institutions in Germany”, UBA, Berlin, 2004.

[13] BMU. “Bundesministerium für Umwelt, Naturschutz und Reaktorsicherheit (BMU)”, Umweltpolitik. BMU, Berlin, 2004.

[14] B. Texte, "Umweltrecht. 15. Auflage. Deutscher Taschenbuch Verlag, München”, Wood, C. Environmental Impact Assessment. A Comparative Review. Second Edition, 2003. 